\title{
G-protein-coupled receptor participates in 20-hydroxyecdysone signaling on the plasma membrane
}

\author{
Mei-Juan Cai ${ }^{\dagger}$, Du-Juan Dong ${ }^{\dagger}$, Yu Wang, Peng-Cheng Liu, Wen Liu, Jin-Xing Wang and Xiao-Fan Zhao*
}

\begin{abstract}
Background: Animal steroid hormones are conventionally known to initiate signaling via a genomic pathway by binding to the nuclear receptors. The mechanism by which 20E initiates signaling via a nongenomic pathway is unclear.

Results: We illustrate that 20 E triggered the nongenomic pathway through a plasma membrane G-protein-coupled receptor (named ErGPCR) in the lepidopteran insect Helicoverpa armigera. The transcript of ErGPCR was increased at the larval molting stage and metamorphic molting stage by 20E regulation. Knockdown of ErGPCR via RNA interference in vivo blocked larval-pupal transition and suppressed 20E-induced gene expression. ErGPCR overexpression in the $\mathrm{H}$. armigera epidermal cell line increased the 20E-induced gene expression. Through ErGPCR, 20E modulated Calponin nuclear translocation and phosphorylation, and induced a rapid increase in cytosolic $\mathrm{Ca}^{2+}$ levels. The inhibitors of T-type voltage-gated calcium channels and canonical transient receptor potential calcium channels repressed the 20E-induced $\mathrm{Ca}^{2+}$ increase. Truncation of the N-terminal extracellular region of ErGPCR inhibited its localization on the plasma membrane and 20E-induced gene expression. ErGPCR was not detected to bind with the steroid hormone analog $\left[{ }^{3} \mathrm{H}\right]$ Pon $\mathrm{A}$.
\end{abstract}

Conclusion: These results suggest that ErGPCR participates in 20E signaling on the plasma membrane.

Keywords: Steroid hormones, G-protein-coupled receptors, Protein phosphorylation, Calcium influx, Signal transduction

\section{Background}

Animal steroid hormones are lipid-soluble molecules conventionally known to initiate signaling via a genomic pathway. Steroid hormones enter the nucleus by freely diffusing through cell membranes to combine with intracellular nuclear receptors for gene transactivation. Nuclear receptors act by forming homodimers or heterodimers. For example, the glucocorticoid receptor [1] and estrogen receptor [2] form a homodimer, and insect ecdysone receptor (EcR) forms a heterodimer with an ultraspiracle protein (USP), the ortholog of retinoid $\mathrm{X}$ receptor in vertebrates [3]. The heat shock proteins Hsp90 and Hsp70 interact with the nuclear receptors to facilitate their DNA

\footnotetext{
* Correspondence: xfzhao@sdu.edu.cn

${ }^{\dagger}$ Equal contributors

The Key Laboratory of Plant Cell Engineering and Germplasm Innovation, Ministry of Education, Shandong Provincial Key Laboratory of Animal Cells and Developmental Biology, School of Life Sciences, Shandong University, Jinan 250100, Shandong, China
}

(C) 2014 Cai et al.; licensee BioMed Central Ltd. This is an Open Access article distributed under the terms of the Creative Commons Attribution License (http://creativecommons.org/licenses/by/2.0), which permits unrestricted use, distribution, and reproduction in any medium, provided the original work is properly credited. The Creative Commons Public Domain Dedication waiver (http://creativecommons.org/publicdomain/zero/1.0/) applies to the data made available in this article, unless otherwise stated.

binding activity in fruit flies [4] and mammals [5]. Hsp90 [6] and Hsc70 [7] have been found to be involved in insect steroid hormone signaling by differential interaction with the nuclear receptors. However, plant steroid hormones, such as brassinosteroids, employ a nongenomic pathway to initiate signaling by combining with plasma membrane receptor kinases for gene transactivation [8]. The brassinosteroids exhibit structural similarity to the steroid hormones of vertebrates and insects [9]. These studies suggest the existence of similar pathways in plants and animals, which should be further studied.

Previous studies indicated that animal steroid hormones can trigger nongenomic actions through the cytoplasmic membrane [10]. For example, estrogen activates phosphoinositide 3 kinase to recruit protein kinase $B$ to the membrane in mammals [11]. A G-protein-coupled seven transmembrane receptor (GPR30) can act as the membrane receptor for estrogen [12], and it has been renamed G-protein-coupled estrogen receptor 1 (GPER) [13]. However, 
GPR30 is located in the endoplasmic reticulum [14] and may be translocated to the plasma membrane [15]. New studies have suggested that GPER is ubiquitinated at the cell surface, and constitutively internalized in an arrestinindependent manner. Moreover, GPER does not recycle to the plasma membrane [16]. GPER acts as a stand-alone membrane receptor of pregenomic action independent on the estrogen nuclear receptor [17]. GPER also functions in the nervous system, and may be a pharmaceutical target [18].

In insects, the ATP-binding cassette transporter E23 can act as a general negative regulator of ecdysteroid signaling by transporting 20E outside of the cell [19]. 20E promotes neuroblast proliferation during metamorphosis partly by suppressing nitric oxide production in $<15 \mathrm{~min}$ without protein synthesis or transcription [20], and the cell membrane receptor of $20 \mathrm{E}$ is assumed to be a leucine-rich repeat receptor kinase [21]. The plasma membrane of the anterior silk gland of Bombyx mori binds $\left[{ }^{3} \mathrm{H}\right]$ ponasterone A $\left(\left[{ }^{3} \mathrm{H}\right]\right.$ Pon $\left.\mathrm{A}\right)$, suggesting that the anterior silk gland may express an unknown membrane 20E receptor [22]. 20E induces intracellular $\mathrm{Ca}^{2+}$ release into the cytoplasm via an unknown G-protein-coupled receptor (GPCR) pathway in the anterior silk gland of silkworms [23]. The Drosophila dopamine receptor DmDopEcR binds $\left[{ }^{3} \mathrm{H}\right]$ Pon $\mathrm{A}$, and is considered as a 20E membrane receptor [24]. Ecdysteroids trigger rapid $\mathrm{Ca}^{2+}$ increase, including intracellular $\mathrm{Ca}^{2+}$ release, and extracellular $\mathrm{Ca}^{2+}$ influx through GPCR in mouse skeletal muscle cells [25]. In our previous study, we demonstrated that $20 \mathrm{E}$ regulates the rapid nuclear translocation and phosphorylation of Calponin for gene expression in Helicoverpa armigera [26]. These findings suggest that $20 \mathrm{E}$ has membrane receptors and a nongenomic signaling pathway.

In this study, we reported an ecdysone-responsible GPCR (ErGPCR) participates in 20E signaling on the plasma membrane. The knockdown of ErGPCR disrupted several biological processes, including the larval-pupal metamorphosis, expression of 20E-induced genes, subcellular translocation and phosphorylation of Calponin, and 20E-induced cytosolic $\mathrm{Ca}^{2+}$ increase.

\section{Results}

\section{ErGPCR is involved in 20E-regulated gene expression}

It has been known that $20 \mathrm{E}$ regulates the gene expression of the nuclear receptor EcRB1 and transcription factors $B r$, USP1, E75B, and HR3 [27]. Suramin disrupts GPCR binding with the $G$ protein by blocking the association of $G$ protein $\alpha$ and $\beta \gamma$ subunits [28]. Suramin is widely used to study GPCR- and G-protein-initiated cell signaling, including the 20E-induced GPCR pathway in the anterior silk gland of silkworms [23], cytosolic $\mathrm{Ca}^{2+}$ increase, and protein kinase $\mathrm{C}$ activation [29]. Thus, the involvement of GPCRs in 20E-induced gene expression was analyzed using the GPCR inhibitor suramin in a lepidopteran $H$. armigera epidermal cell line (HaEpi cell line, established in our laboratory) [30]. 20E significantly promoted the expression of EcRB1, BrZ2, HHR3, and USP1 compared with the DMSO solvent control. However, the 20E-induced transcript increase was repressed by the addition of suramin (Figure 1). These results suggest that GPCRs are probably involved in 20E-regulated mRNA levels.

We identified six GPCR candidates from the expressed sequence tags (EST) of the cDNA library of the HaEpi cell line using BLASTX assay (http://www.ncbi.nlm.nih. gov/) (Additional file 1: Figure S1, Table S1). The mRNA levels of six GPCR candidates were upregulated by $20 \mathrm{E}$ induction, and two non-GPCR ESTs were unaffected. Knockdown of No. 16666 and ErGPCR in the HaEpi cells using RNA interference (RNAi) decreased EcRB1, $B r Z 2, H H R 3$, and USP1 transcript levels in 20E induction. The knockdown of the other four GPCR candidates affected one to three 20E-induced gene transcripts (Additional file 1: Figure S2). These results suggest the involvement of GPCRs in 20E-induced gene expression.

ErGPCR was further studied regarding its expression profile during development. The deduced amino acid sequence of ErGPCR contains a signal peptide at the $\mathrm{N}$-terminus and seven transmembrane domains (Additional file 1: Figure S3). ErGPCR belongs to methuselah-like proteins in the class B secretin GPCR family based on NCBI Blast analysis (http://blast.ncbi.nlm.nih.gov/Blast. cgi). ErGPCR has 57\% identity with Spodoptera frugiperda GPCR, 32\% with Tribolium castaneum GPCR, and 30\% with Drosophila melanogaster GPCR (Additional file 1:

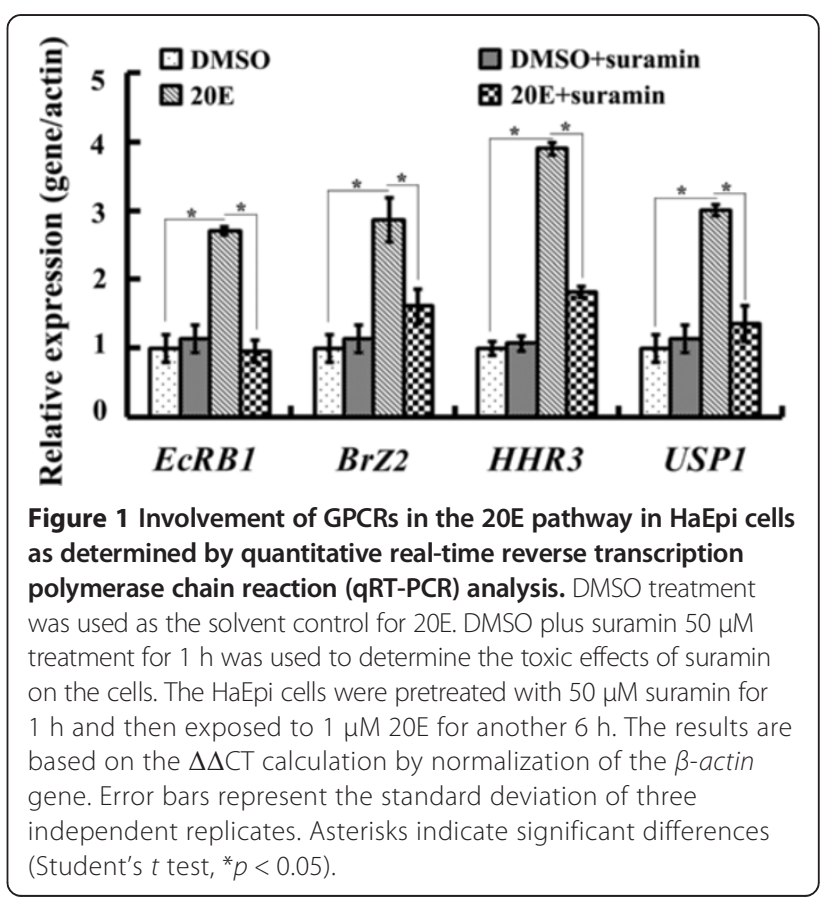


Figure S4). However, D. melanogaster DmDopEcR, Homo sapiens GPR30, and $H$. sapiens beta-2 adrenergic receptor (AR) are not found by BLASTX analysis. This finding suggests that ErGPCR is less similar to DmDopEcR, GPR30, and AR. Phylogenetic analysis indicated that ErGPCR does not cluster with DmDopEcR, GPR30, and AR. These results illustrate that these GPCRs belong to different GPCR groups (Additional file 1: Figure S5).

The transcript level of ErGPCR was increased at the larval molting stage $(5 \mathrm{M})$ and metamorphic molting stage (sixth-instar $72 \mathrm{~h}$ larvae to pupae) in the tissues (Figure 2). Given that the $20 \mathrm{E}$ titer is higher during molting and
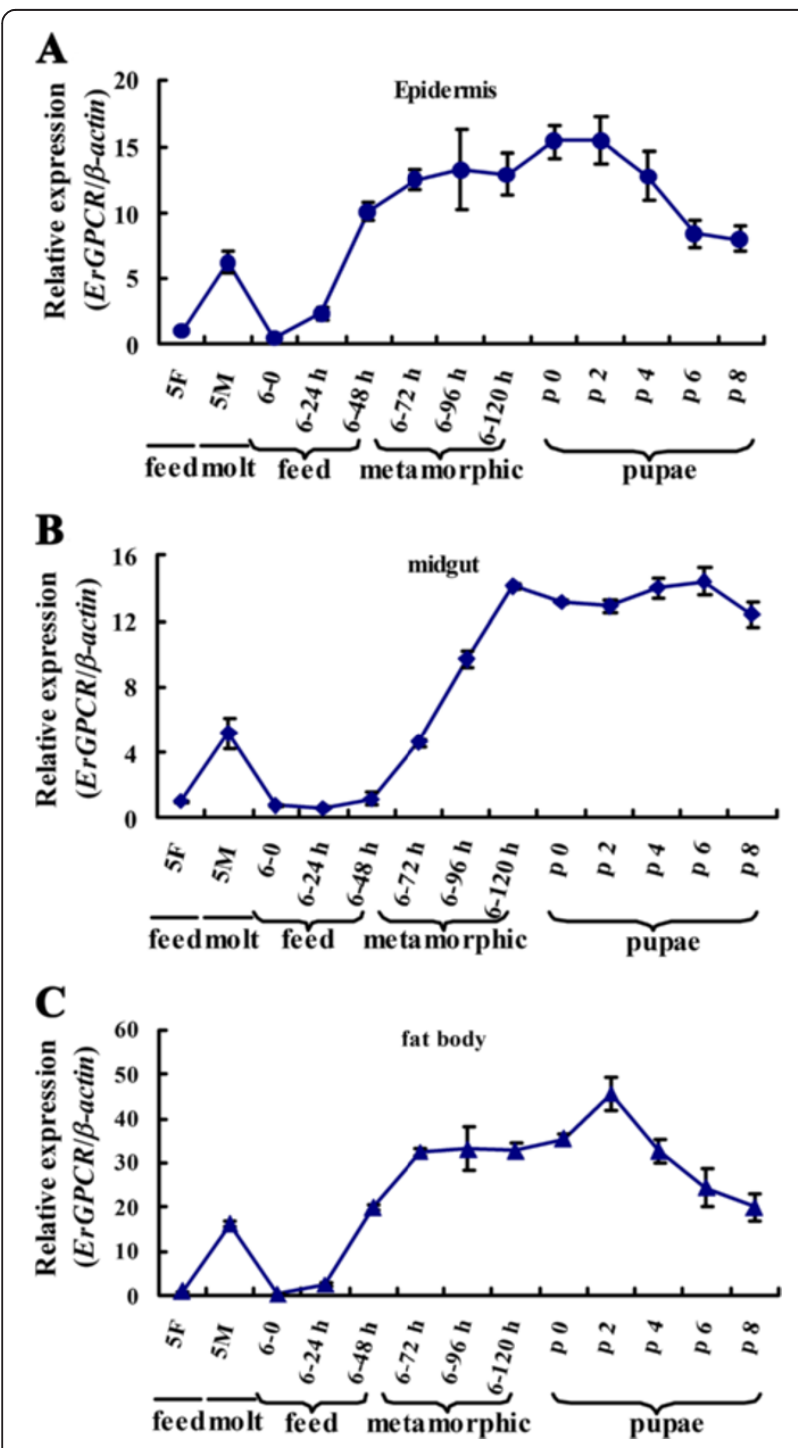

Figure 2 The increased transcripts of ErGPCR during molting and metamorphosis. (A), (B) and (C) ErGPCR is highly expressed during molting and metamorphosis in epidermis, midgut and fat body detected by qRT-PCR. $\mathbf{5} \mathbf{F}$ is the fifth instar $12 \mathrm{~h}$ larvae; $\mathbf{5} \mathbf{M}$ is the fifth instar molting larvae; $\mathbf{6 - 0}$ to $\mathbf{6 - 1 2 0} \mathbf{~}$ are the 6 th instar larvae in hours; p 0 to p 8 are the pupae in days. metamorphosis in lepidopteran insect Manduca sexta [27], the hormone induction on the mRNA levels of ErGPCR was examined. The ErGPCR transcript level was upregulated in the midgut from $3 \mathrm{~h}$ to $24 \mathrm{~h}$ after $20 \mathrm{E}$ injection into the sixth-instar larvae. JH III injection into the sixth-instar larvae did not affect the ErGPCR transcript levels, but repressed the 20E-induced upregulation of ErGPCR (Figure 3). These data suggest that ErGPCR mRNA level is upregulated by $20 \mathrm{E}$ signaling. To confirm that 20E upregulates $\operatorname{ErGPCR}$, we knocked down the nuclear receptor of 20E, EcRB1, and analyzed the transcript of ErGPCR. When EcRB1 was knocked down, the upregulation of ErGPCR induced by $20 \mathrm{E}$ was blocked (Additional file 1: Figure S6). These results reveal that 20E upregulates ErGPCR transcript via the nuclear receptor EcRB1.

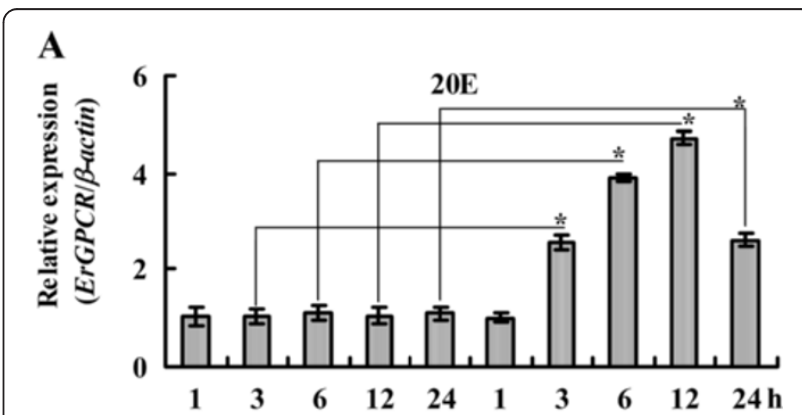

B

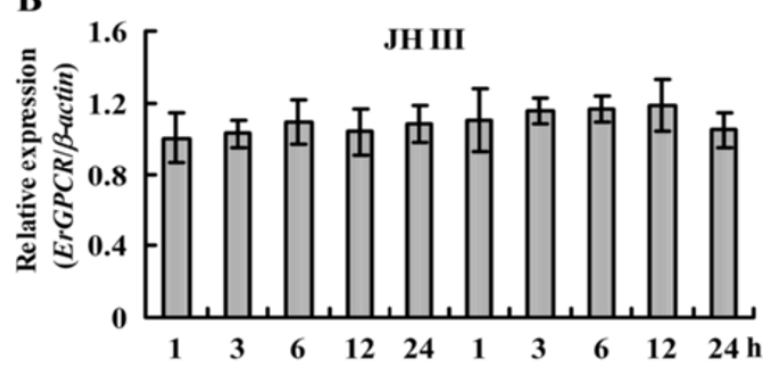

C

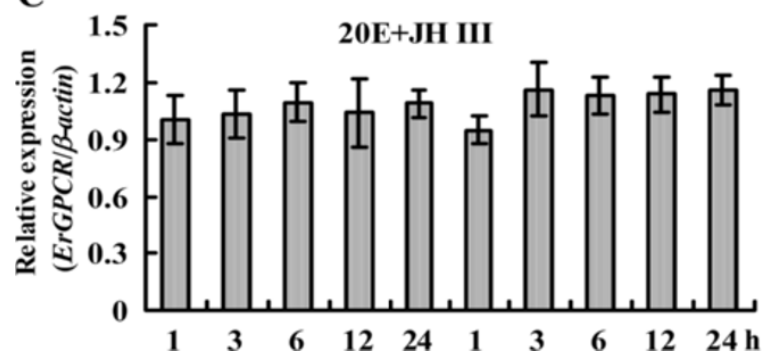

Figure 3 Hormonal induction of ErGPCR in the midgut by injection of $20 \mathrm{E}(\mathrm{A})$ or $\mathrm{JH}$ III (B) or $20 \mathrm{E}+\mathrm{JH}$ III (C) into the 6th instar $6 \mathrm{~h}$ larvae ( $500 \mathrm{ng} / \mathrm{larva})$ analyzed by qRT-PCR. DMSO is a solvent control. $\beta$-actin gene was used as the quantitative control for the mRNA. The asterisks indicate significant differences between 20E treatment and DMSO solvent control by student's $t$ test analysis from three independent repeats $\left({ }^{*} p<0.05, n=3\right.$ ). 
ErGPCR is involved in the larval-pupal transition in vivo by regulating gene expression

The function of ErGPCR in larval-pupal transition was determined through RNAi by injecting $d s E r G P C R$ into the larval hemocoel. The knockdown of ErGPCR blocked larval-pupal transition (Figure 4A). In the dsRNA of green fluorescent protein (dsGFP)-injected control, $90 \%$ of the larvae pupated, whereas $10 \%$ died. However, in $d s E r G P C R$ treatment, only $29 \%$ of the larvae pupated, $50 \%$ died, and $21 \%$ displayed larval-pupal chimeras (Figure 4B). Of the 29\% that pupated after ErGPCR knockdown, the duration of development was significantly delayed compared with the dsGFP control: a $23 \mathrm{~h}$ delay from fifth instar to the sixth instar, and a $52 \mathrm{~h}$ delay from the sixth instar to the pupal stage (Figure 4C). RT-PCR showed that ErGPCR was significantly knocked down by four consecutive

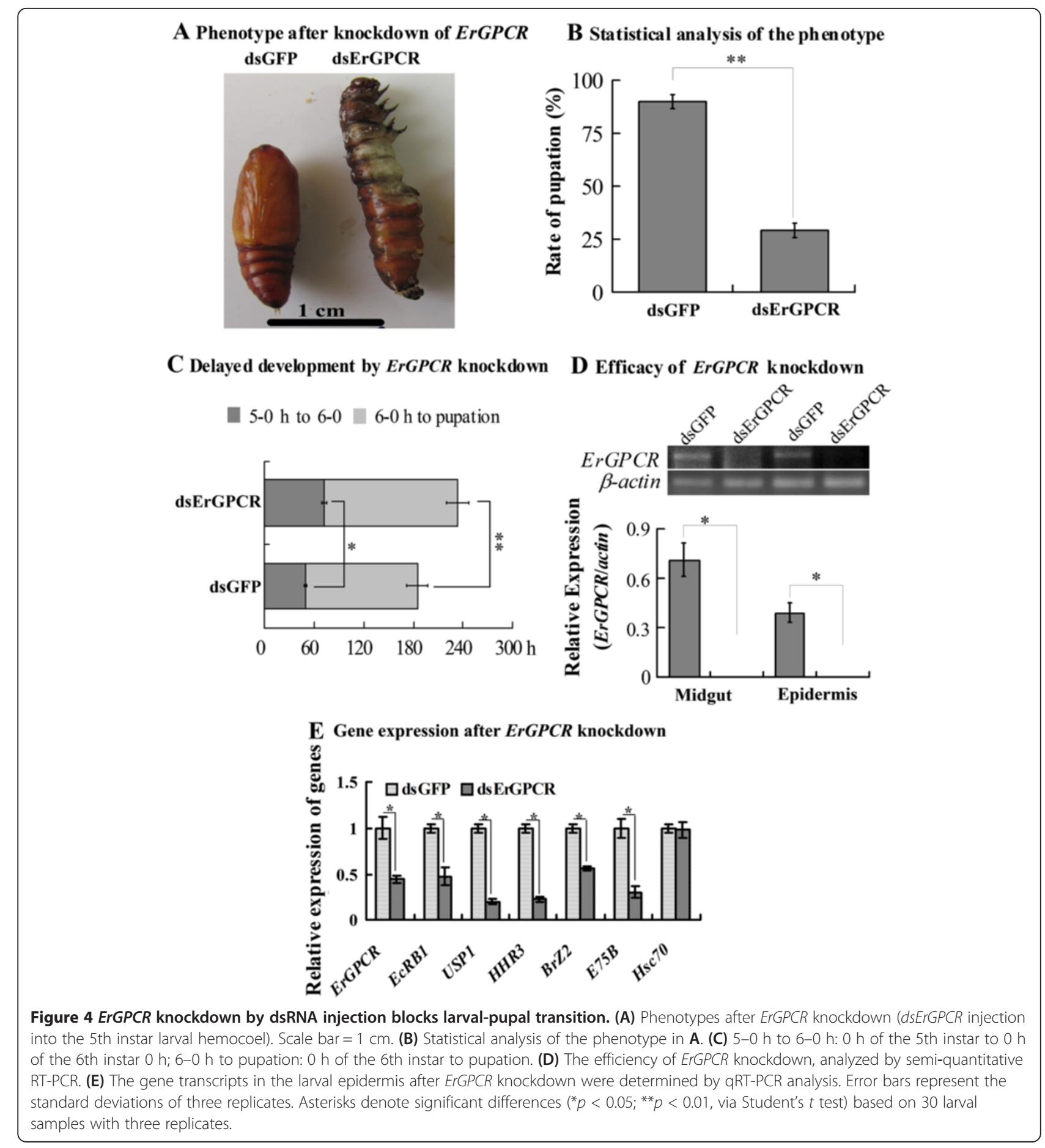


dsErGPCR injections into the larvae (Figure 4D). The transcript levels of the genes involved in the 20E pathway, including EcRB1, USP1, HHR3, BrZ2, and E75B, were decreased in the larval epidermis after $\operatorname{ErGPCR}$ knockdown (Figure 4E). These results suggest that ErGPCR is related to larval-pupal transition and gene expression in vivo.

\section{ErGPCR is located on the membrane and is necessary for 20E-induced gene expression}

Immunocytochemical analysis using rabbit anti-ErGPCR polyclonal antibodies showed that ErGPCR was located on the plasma membrane of HaEpi cells. The green fluorescence of ErGPCR overlapped with the red-stained cell membrane to display an orange color by confocal laser scanning microscopy (Figure 5A). Moreover, the overexpression of ErGPCR-GFP (C-terminal with GFP) was also located on the cell plasma membrane (Figure 5B). ErGPCR knockdown in the HaEpi cells decreased the 20E-induced transcript levels of EcRB1, USP1, HHR3, BrZ2, and E75B compared with the $d s G F P$-treated control (Figure $5 \mathrm{C}$ ). By contrast, ErGPCR overexpression led to an increase in the transcript levels of EcRB1, BrZ2, HHR3, and USP1 (Figure 5D). Moreover, 20E upregulated the mRNA level of insulator body protein $\bmod (\operatorname{mdg} 4) 1 a$ not through EcRB1 but through ErGPCR (Figures 5E and F). These results suggest that ErGPCR may serve as the initiation step of 20E signal amplification on the plasma membrane as nongenomic or pregenomic action before the hierarchical control of 20E-induced genomic action.

\section{$20 \mathrm{E}$ regulates protein nuclear translocation and phosphorylation via ErGPCR}

The nongenomic pathway is characterized by rapid protein translocation and phosphorylation [31]. The Calponin protein has been demonstrated to undergo quick nuclear translocation and phosphorylation by 20E induction [26]. Thus, ErGPCR was knocked down in the HaEpi cells to determine its function in 20E-regulated rapid translocation and phosphorylation of Calponin. Calponin was mainly localized in the cytoplasm in the DMSO-negative control cells, but was translocated into the nucleus after 20E induction. However, after ErGPCR knockdown, 20E could not induce the nuclear translocation of Calponin (Figure 6A). Moreover, the 20E-mediated Calponin phosphorylation was suppressed when ErGPCR was silenced (Figure 6B). The protein synthesis inhibitor anisomycin did not inhibit 20E-induced Calponin phosphorylation (Figure 6C). These results suggest that 20E regulates Calponin nuclear translocation and phosphorylation via ErGPCR.

\section{$20 \mathrm{E}$ regulates cellular $\mathrm{Ca}^{2+}$ release and influx via ErGPCR to regulate gene expression}

The increase in cellular $\mathrm{Ca}^{2+}$ is another characteristic of the nongenomic pathway of steroid hormones [32]. Thus,
ErGPCR was knocked down in the HaEpi cells to determine the function of ErGPCR in the rapid 20E-regulated $\mathrm{Ca}^{2+}$ increase. When the cells were incubated in calciumfree buffer (DPBS), cytosolic $\mathrm{Ca}^{2+}$ level increased rapidly by $20 \mathrm{E}$ treatment, and peaked at approximately $50 \mathrm{~s}$, then declined to a lower level at $120 \mathrm{~s}$. Following the addition of $1 \mathrm{mM}$ calcium into DPBS at $120 \mathrm{~s}$, the cytosolic $\mathrm{Ca}^{2+}$ levels gradually increased and then remained constant. However, suramin $(50 \mu \mathrm{M})$ pretreatment for $1 \mathrm{~h}$ inhibited the 20E-induced rapid increase in cytosolic $\mathrm{Ca}^{2+}$ levels (Figure 7A). When ErGPCR was knocked down by RNAi, the $20 \mathrm{E}$-induced $\mathrm{Ca}^{2+}$ increase, including intracellular $\mathrm{Ca}^{2+}$ release, and extracellular $\mathrm{Ca}^{2+}$ influx, was also inhibited compared with the control (Figure 7B). These findings suggest that 20E induces rapid intracellular $\mathrm{Ca}^{2+}$ release and extracellular $\mathrm{Ca}^{2+}$ influx via ErGPCR.

Various calcium channel blockers, including the T-type voltage-gated calcium channel inhibitor flunarizine dihydrochloride (FL), L-type calcium channel inhibitor verapamil hydrochloride (Ve) [33], transient receptor potential (TRP) calcium channel store-operated channel (SOC) inhibitor 2-aminoethoxydiphenyl borate (2-APB) [34], and receptor-operated (ROC) TRPC3 channel inhibitor pyrazole (Pyr3) [35], were employed to determine the involvement of calcium channels in 20E-induced extracellular $\mathrm{Ca}^{2+}$ influx. The 20E-induced $\mathrm{Ca}^{2+}$ influx was restrained by $50 \mu \mathrm{M}$ FL without affecting intracellular $\mathrm{Ca}^{2+}$ release. By contrast, 20E-induced $\mathrm{Ca}^{2+}$ release and influx were unaffected by $100 \mu \mathrm{M}$ Ve (Figure 7C). The 2-APB inhibitor $(10 \mu \mathrm{M}$ to $100 \mu \mathrm{M})$ had no effect on the $20 \mathrm{E}$-induced $\mathrm{Ca}^{2+}$ release and influx. However, $10 \mu \mathrm{M}$ Pyr3 suppressed the 20 E-induced $\mathrm{Ca}^{2+}$ influx, but had no effect on intracellular $\mathrm{Ca}^{2+}$ release (Figure 7D). These results reveal that T-type calcium channels and TRPC3 channels are involved in 20E-induced $\mathrm{Ca}^{2+}$ flux.

To investigate the effect of the cellular $\mathrm{Ca}^{2+}$ increase on the 20E-induced gene expression and 20E-induced Calponin phosphorylation, we performed qRT-PCR and western blot. The 20E-induced upregulation of EcRB1, BrZ2, HHR3, and USP1 was suppressed by FL and Pyr3 (Figure 7E). Meanwhile, the 20E-induced phosphorylation of Calponin was inhibited (Figure 7F). By contrast, Ve and 2 -APB inhibitors had no effect on the 20E-induced gene expression and 20E-induced Calponin phosphorylation. These results show that the 20E-induced rapid intracellular $\mathrm{Ca}^{2+}$ increase is required for 20E-regulated gene expression and protein phosphorylation.

To examine the mechanism by which $20 \mathrm{E}$ regulates gene expression through ErGPCR and $\mathrm{Ca}^{2+}$ signaling, ChIP experiments were performed by anti-RFP antibody in the EcRB1-RFP-overexpressing HaEpi cells. In M. sexta, one ecdysone response element (EcRE1, GGGGTCAATG AACCG) was identified in 20E reporter gene hormone receptor 3 (HR3). 20E regulates EcRB1/USP1 heterodimer 


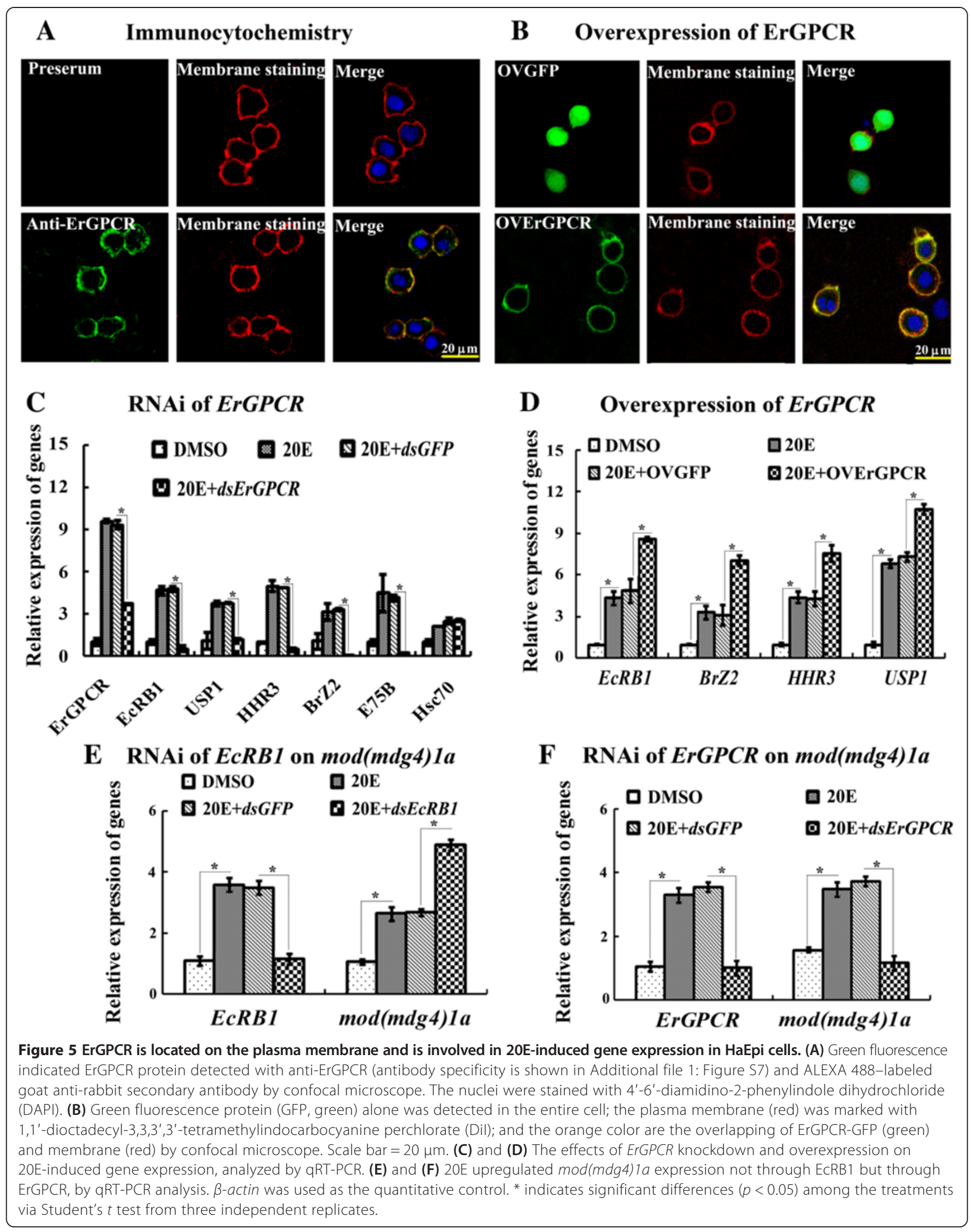




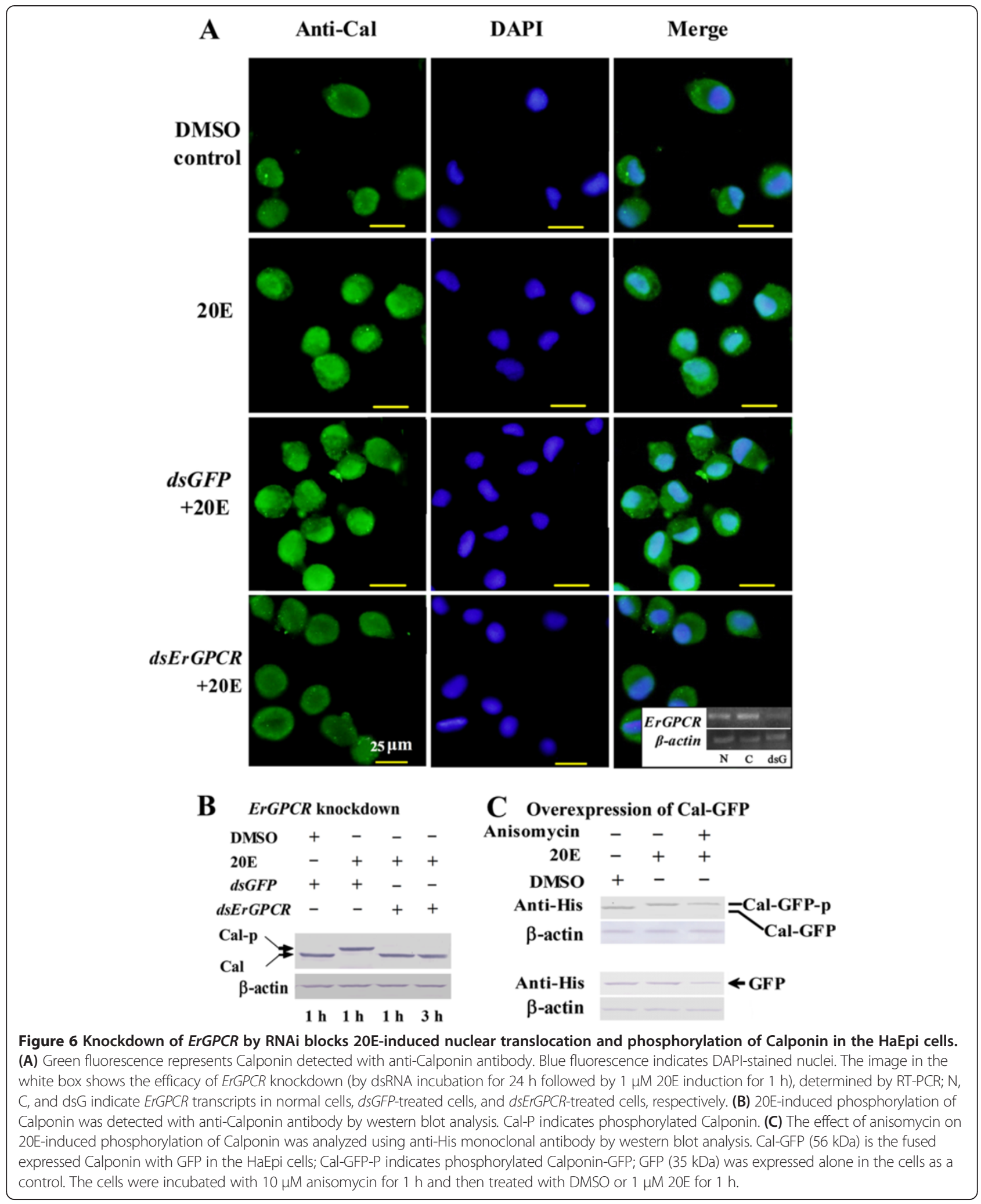

binding to EcRE to regulate gene transcription [36]. We cloned the 5 ' regulatory region of Helicoverpa HR3 (HHR3) that contains putative EcRE (GGGGTCAA
TGAACTG), which has one "T" different from EcRE1 in MHR3. The EcRE from HHR3 is proven to be active by GFP-plasmid examination. Fewer PCR product (EcRE) 

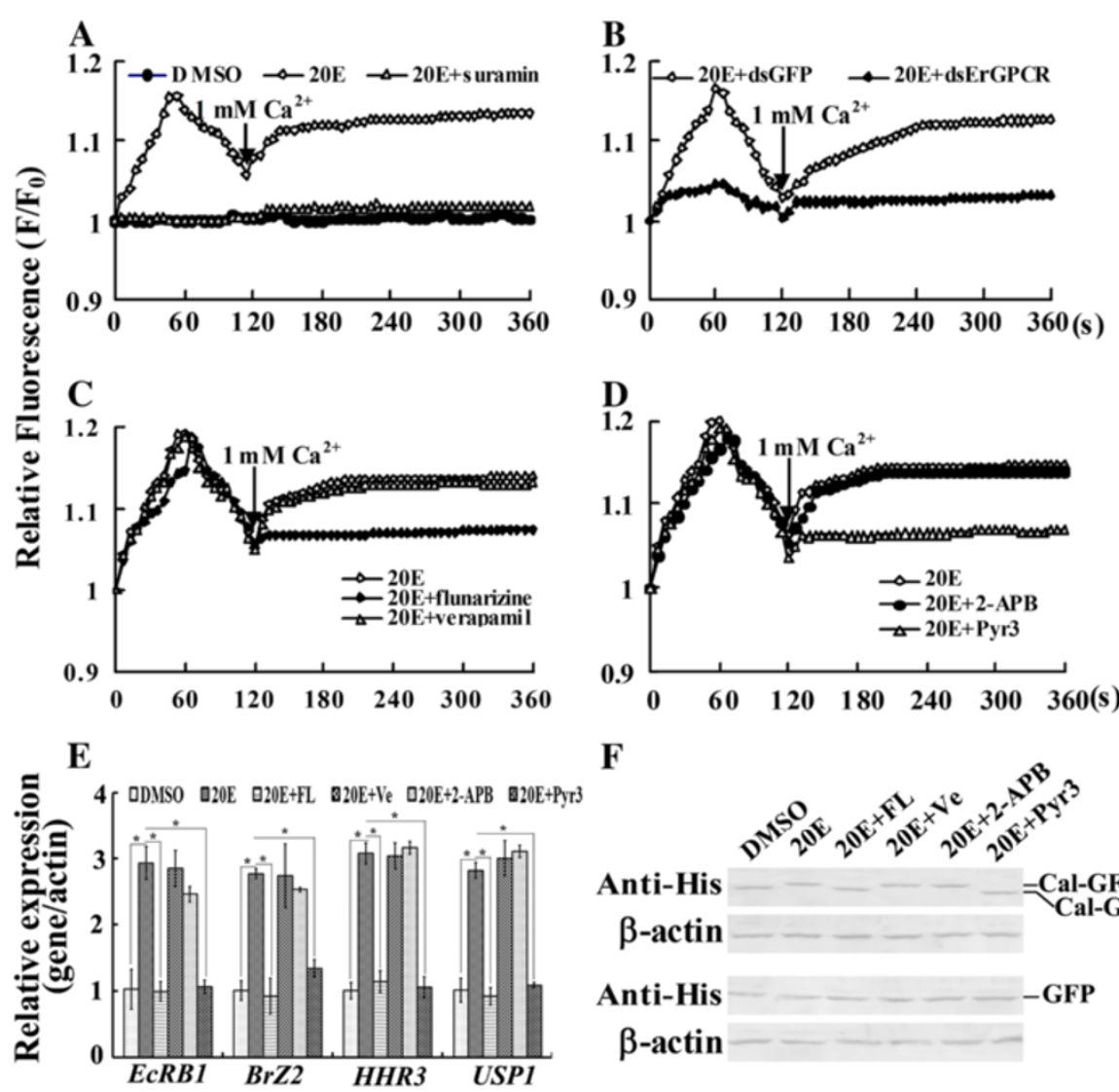

Figure 7 ErGPCR is involved in the 20E-induced increase in cytosolic $\mathrm{Ca}^{2+}$ levels. (A) Suramin inhibited the 20E-induced $\mathrm{Ca}^{2+}$ increase $(1 \mu \mathrm{M}$ $20 E, 1 \mathrm{mM}$ calcium chloride, $50 \mu \mathrm{M}$ suramin). F represents the fluorescence of cells after treatment, whereas $F_{0}$ denotes the average fluorescence of cells before treatment. Fluorescence was detected every 6 s for 360 s using a Laser Scan Confocal Microscope Carl Zeiss LSM 700 (Thornwood, NY, USA) at $555 \mathrm{~nm}$ and then analyzed using the Image Pro-Plus software. (B) ErGPCR knockdown using dsRNA (5 $\mu \mathrm{g} / \mathrm{mL}$ ) incubation inhibited the 20E-induced $\mathrm{Ca}^{2+}$ increase. (C) The T-type calcium channel blocker flunarizine dihydrochloride (FL, $50 \mu \mathrm{M}$ ) inhibited the 20E-indued $\mathrm{Ca}^{2+}$ influx. The L-type calcium channel blocker verapamil hydrochloride $(\mathrm{Ve}, 100 \mu \mathrm{M})$ did not affect the $20 \mathrm{E}$-induced $\mathrm{Ca}^{2+}$ influx. (D) The transient receptor potential (TRP) channel blocker pyrazole (Pyr3, $10 \mu \mathrm{M})$ inhibited the 20E-induced $\mathrm{Ca}^{2+}$ increase. 2-Aminoethoxydiphenyl borate (2-APB) (10 $\mu \mathrm{M}$ to $\left.100 \mu \mathrm{M}\right)$ did not affect 20E-induced $\mathrm{Ca}^{2+}$ influx. (E) qRT-PCR showing the involvement of $\mathrm{Ca}^{2+}$ signal in 20E-induced gene expression. Cells were incubated in $1 \mu \mathrm{M}$ $20 \mathrm{E}$ for $6 \mathrm{~h}$ after different inhibitors pretreatment for $1 \mathrm{~h}$ and the RNA was isolated for qRT-PCR. $\beta$-actin was used as the quantitative control. *indicates significant differences $(p<0.05)$ among the treatments via Student's $t$ test from three independent replicates. $(\mathbf{F})$ Western blot showing the involvement of $\mathrm{Ca}^{2+}$ signal in 20E-induced Calponin phosphorylation. plEx-4-Cal-GFP was overexpressed in HaEpi cells for $48 \mathrm{~h}$. The cells were treated with $1 \mu \mathrm{M} 20 \mathrm{E}$ for $1 \mathrm{~h}$ after different inhibitors pretreatment for $1 \mathrm{~h}$. The GFP was overexpressed as controls.

was detected from the immunoprecipitates in the pIEx-4RFP-transfected control samples after various treatments by anti-RFP antibody, because the RFP recognized by anti-RFP antibody did not bind to DNA. By contrast, in the pIEx-4-EcRB1-RFP-transfected cells, the PCR product (EcRE) was detected from the immunoprecipitates in 20E induction by anti-RFP antibody. However, after ErGPCR knockdown, the PCR product (EcRE) was significantly decreased compared with the $d s G F P$ treatment control (Figure 8A). These results suggest that 20E via ErGPCR regulates EcRB1 binding to EcRE to regulate the 20Einduced gene transcription.

Similarly, in the pIEx-4-RFP-transfected control samples, fewer PCR product (EcRE) was detected in the immunoprecipitate by anti-RFP antibody after various treatments.
By contrast, in the pIEx-4-EcRB1-RFP-transfected samples, the PCR product containing EcRE was detected in 20E induction by anti-RFP antibody, which recognized the binding of EcRB1-RFP to EcRE. However, fewer DNA product containing EcRE was detected after the addition of inhibitors FL and Pyr3. Ve and 2-APB had no effect on the PCR product (EcRE) (Figure $8 \mathrm{~B}$ ). These results suggest that $20 \mathrm{E}$ via cellular $\mathrm{Ca}^{2+}$ signaling modulates the binding of EcRB1 to EcRE, and regulates the 20E-induced gene transcription.

\section{$\mathrm{N}$-terminal extracellular region is essential to ErGPCR} function in the 20E signaling pathway

Truncated mutations of ErGPCR in the N-terminal region (aa 20 to 197) (OVErGPCR ${ }^{\triangle 20-197 \text { aa }}$ ) or second inner loop 


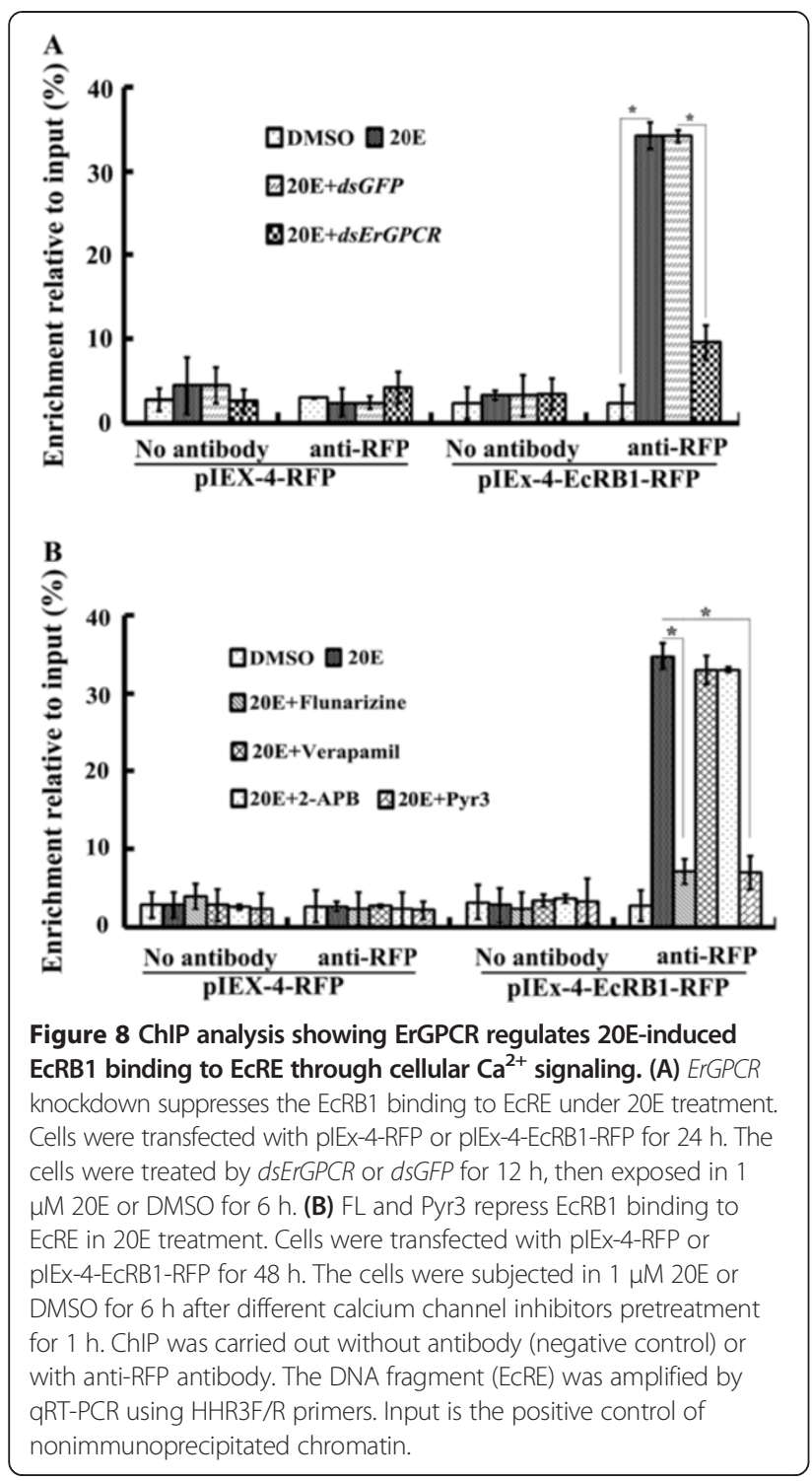

(aa 275 to 308) (OVErGPCR ${ }^{\triangle 275-308 \text { aa }}$ ) were overexpressed by fusing with GFP to analyze the functional domain of ErGPCR in the 20E signaling pathway (Figure 9A). Overexpressed full-length ErGPCR (OVErGPCR) was located on the plasma membrane. However, the $\mathrm{N}$-terminal region-truncated ErGPCR (OVErGPCR ${ }^{\triangle 20-197}$ aa) was in the cytoplasm, whereas the second inner loop truncation $\left(\mathrm{OVErGPCR}{ }^{\triangle 275-308}\right.$ aa) was located in both the plasma membrane and cytoplasm (Figures $9 \mathrm{~B}$ and $\mathrm{C}$ ). Correlated with its location, the truncation of the $\mathrm{N}$-terminal extracellular region of ErGPCR (OVErGPCR ${ }^{\triangle 20-197 \text { aa) }}$ caused a decrease in the 20E-induced transcript levels of EcRB1, $B r Z 2, H H R 3$, and USP1 compared with the full-length OVErGPCR. By contrast, truncation of the second inner loop of ErGPCR (OVErGPCR ${ }^{\triangle 275-308}$ aa) did not affect the 20E-induced transcript levels of EcRB1, BrZ2, HHR3, and USP1 (Figure 9D). These results indicate that the complete structure of ErGPCR is essential to its plasma membrane location, and the $\mathrm{N}$-terminal extracellular region is required for ErGPCR function in the 20E signaling pathway.

\section{ErGPCR is not detected to bind with the $20 \mathrm{E}$ analog $\left[{ }^{3} \mathrm{H}\right]$ Pon A}

ErGPCR and EcRB1 were overexpressed in HaEpi cells by fusing with GFP at the C-terminus (Figure 10A) for the binding experiments. No increase in $\left[{ }^{3} \mathrm{H}\right]$ Pon $\mathrm{A}(0.1 \mathrm{nM})$ was detected with the increase in cell numbers $\left(1 \times 10^{4}\right.$ cells to $100 \times 10^{4}$ cells) in ErGPCR-GFP-transfected cells compared with the normal cells, GFP-overexpressed cells, or EcRB1-GFP-overexpressed cells (Figure 10B). The increase in $\left[{ }^{3} \mathrm{H}\right]$ Pon $A$ was not detected in the plasma membrane fractions ( $5 \mu \mathrm{g}$ to $500 \mu \mathrm{g}$ ) from HaEpi cells that overexpressed ErGPCR-GFP compared with that in the membrane fractions from the normal cells and GFP-overexpressed cells (Figure 10C). These results suggest that cells or cell membrane fractions could bind with $\left[{ }^{3} \mathrm{H}\right]$ Pon A in a cell- or cell membrane fraction-dependent manner. However, overexpression of ErGPCR does not increase $\left[{ }^{3} \mathrm{H}\right]$ Pon A binding by this analysis.

\section{Discussion}

Although studies have shown that GPCRs are involved in 20E signaling, definitive evidence of this involvement is scarce. Our study reveals that ErGPCR regulates 20E signaling on the plasma membrane. Through ErGPCR, $20 \mathrm{E}$ regulates gene expression, fast protein translocation and phosphorylation, rapid intracellular $\mathrm{Ca}^{2+}$ increase, and larval-pupal transition.

\section{$20 \mathrm{E}$ regulates genomic action through the ErGPCR-mediated nongenomic pathway}

$20 \mathrm{E}$ initiates the genomic pathway by binding with its nuclear hormone receptor EcR to regulate gene expression for metamorphosis [37]. 20E upregulated the mRNA levels of EcRB1, USP1, HHR3, BrZ2, and E75B. Knockdown of ErGPCR repressed the binding of EcRB1 to EcRE thus blocked 20E-induced expression of EcRB1, USP1, HHR3, $B r Z 2$, and $E 75 B$ in the cell line and larvae, which resulted in blocking the 20E genomic pathway, thereby inhibiting metamorphosis. These results indicate that $20 \mathrm{E}$ initiates a nongenomic pathway to regulate a 20E-mediated genomic pathway via ErGPCR. In positive feedback, ErGPCR transcript was upregulated by $20 \mathrm{E}$ via EcRB1. 20E does not act through $E c R B 1$ to upregulate the mRNA level of the insulator body protein $\bmod (m d g 4) 1 a$ in HaEpi cells [38]. Instead, $\bmod (m d g 4) 1 a$ is upregulated by $20 \mathrm{E}$ through ErGPCR. These results suggest the existence of various pathways in $20 \mathrm{E}$ signaling. The reason that knockdown of EcRB1 repressed $E r G P C R$ but did not repress $\bmod (\operatorname{mdg} 4) 1 a$ 


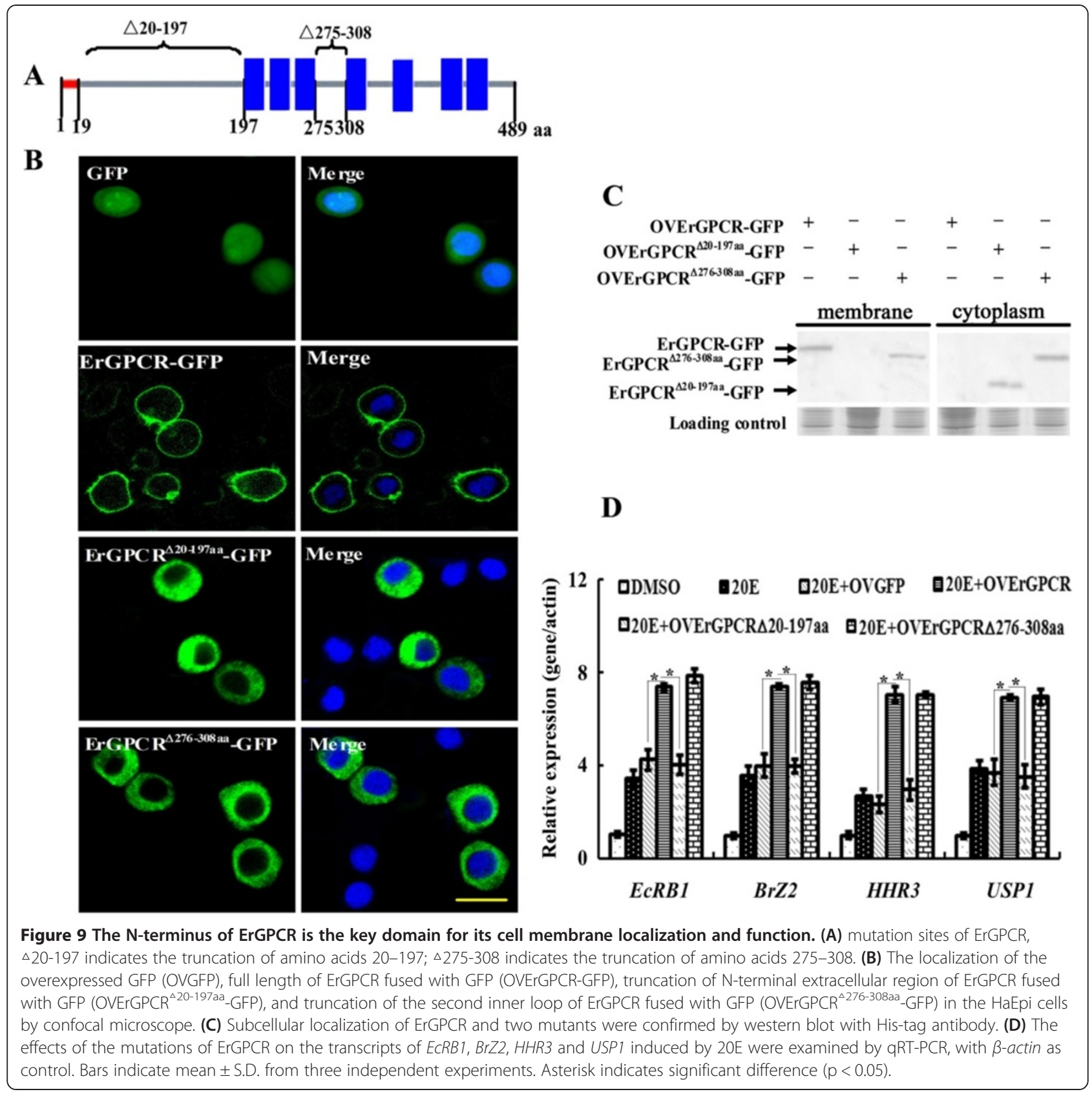

might because the time difference of mRNA transcription and protein translation of ErGPCR.

Steroid hormones, such as mammalian estrogen and insect ecdysone, are conventionally thought to exert their actions through binding to intracellular receptors because of their small molecules and lipid solubility. However, growing evidence indicates that steroid hormones also exert rapid cell surface-initiated actions by binding to membrane receptors [39], such as the estrogen membrane receptor GPR30 [14]. Rapid protein subcellular translocation and phosphorylation (within minutes) are the outcomes of a nongenomic signaling pathway [24]. 20E regulates the rapid nuclear translocation and phosphorylation of Calponin for gene transactivation in $H$. armigera [26]. We found that $20 \mathrm{E}$ regulated Calponin nuclear translocation and subsequent phosphorylation through ErGPCR. This finding suggests that $20 \mathrm{E}$ functions in the membrane via a nongenomic pathway to regulate protein translocation and phosphorylation, which may contribute to the activation of transcription factors and formation of transcription complexes. 


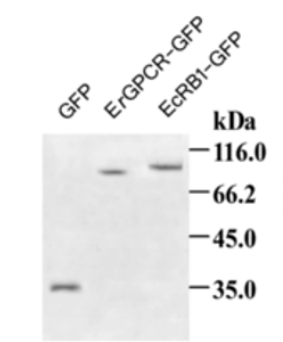

A Overexpression of GFP ERGPCR-GFP and EcRB1-GFP

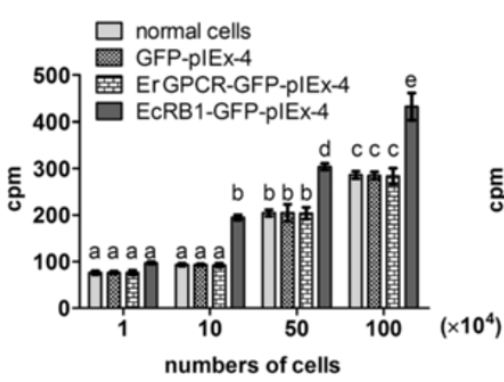

B Binding of $\left[{ }^{3} \mathrm{H}\right] \mathrm{PoA}$ to the whole HaEpi cells

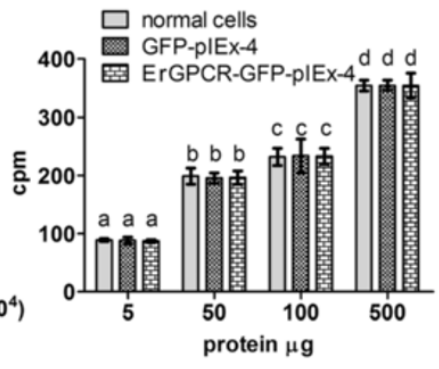

C Binding of $\left[{ }^{3} \mathrm{H}\right] \mathrm{PoA}$ to the membrane fractions of HaEpi cells

Figure 10 Binding assay of $\left[{ }^{3} \mathrm{H}\right]$ Pon $A$ to whole cells or membrane fractions. (A) Western blot analysis of the overexpressed GFP, ErGPCRGFP and EcRB1-GFP. (B) Binding of $\left[^{3} \mathrm{H}\right]$ Pon $\mathrm{A}$ to the whole HaEpi cells that expressed GFP, ErGPCR-GFP or EcRB1-GFP, respectively. The cells (1-100 $\times$ $10^{4}$ ) were incubated with $\left.0.1 \mathrm{nM} \mathrm{[3} \mathrm{H}\right]$ Pon A $(5740 \mathrm{cpm})$ for $1 \mathrm{~h}$ at $27^{\circ} \mathrm{C}$, respectively. (C) The membrane fractions $(5,50,250,500 \mu \mathrm{g}$ membrane proteins) isolated from above cells were incubated with $0.1 \mathrm{nM}\left[{ }^{3} \mathrm{H}\right]$ Pon $\mathrm{A}$ for $1 \mathrm{~h}$ at $27^{\circ} \mathrm{C}$, respectively. cpm: counts per minute of $\left[{ }^{3} \mathrm{H}\right] \mathrm{Pon} \mathrm{A}$. The data marked with different small letters indicate a significant difference at 0.05 levels by the one-way ANOVA with Duncan's test.

\section{ErGPCR is involved in 20E-increased cytosolic $\mathrm{Ca}^{2+}$ levels} $20 \mathrm{E}$ increases the cytosolic $\mathrm{Ca}^{2+}$ levels by promoting the release of $\mathrm{Ca}^{2+}$ from the intracellular endoplasmic reticulum via an unknown GPCR in silkworm silk glands [23]. 20E also regulates $\mathrm{Ca}^{2+}$ influx from extracellular sources via an unknown GPCR that activates calcium channels in murine skeletal muscles [25]. Voltage-gated calcium channels are essential in regulating extracellular $\mathrm{Ca}^{2+}$ influx in a wide variety of tissues [40]. T-type $\mathrm{Ca}^{2+}$ channels are involved in 20E-induced nuclear and DNA fragmentation in silkworm silk glands [23]. GPCRs serve as chaperones and interact with voltage-gated calcium channels to form complexes [41]. Our data show that $20 \mathrm{E}$ regulates rapid intracellular $\mathrm{Ca}^{2+}$ release and extracellular $\mathrm{Ca}^{2+}$ influx through ErGPCR, and T-type voltage-gated $\mathrm{Ca}^{2+}$ channels are involved in $\mathrm{Ca}^{2+}$ influx.

In addition, we found that the $20 \mathrm{E}$-induced $\mathrm{Ca}^{2+}$ influx was also inhibited by the TRP channel inhibitor Pyr3. This result suggests that TRP channels are also involved in 20Einduced $\mathrm{Ca}^{2+}$ influx. TRP channels are non-voltage-gated $\mathrm{Ca}^{2+}$ channels involved in $\mathrm{Ca}^{2+}$ entry [42]. TRP channels are classified into six subfamilies according to their primary structure and function, including ROC and SOC [43]. GPCRs directly or indirectly modulate several TRP channels $[44,45]$. TRP channels are associated with steroid hormones in mammals [46]. Rapid calcium release or influx in the cells is the outcome of nongenomic signaling. Calcium is an important secondary messenger that regulates numerous essential physiologic processes, including protein kinase $\mathrm{C}$ activation, for further protein phosphorylation [47] and gene transcription. In our study, when the cellular $\mathrm{Ca}^{2+}$ was blocked by inhibitors, 20E-induced gene expression and the phosphorylation of Calponin were blocked. These findings confirm the function of calcium on gene expression and protein phosphorylation as the secondary messenger, and reveal that $20 \mathrm{E}$ regulates the cellular calcium via ErGPCR to regulate the genomic pathway.

\section{ErGPCR does not bind with the steroid hormone analog $\left[{ }^{3} \mathrm{H}\right]$ Pon $\mathrm{A}$}

In classical GPCR signaling pathways, ligands bind to cell surface transmembrane receptors, such as the $\beta 2$ ARs, and cause conformational changes in their transmembrane and intracellular domains [48]. Numerous studies have reported the binding of several GPCRs with 20E, such as the binding of DmDopEcR with $\left[{ }^{3} \mathrm{H}\right]$ Pon $\mathrm{A}[24]$, or an unknown GPCR in the anterior silk gland of silkworms binding with $\left[{ }^{3} \mathrm{H}\right]$ Pon $\mathrm{A}$ [22]. However, we did not detect the binding of ErGPCR with $\left[{ }^{3} \mathrm{H}\right]$ Pon A using the whole cells and cell membrane fractions by overexpressing ErGPCR in HaEpi cells. Thus, ErGPCR is likely transiently activated by $20 \mathrm{E}$ without any stable ligand binding.

Based on NCBI Blast analysis (http://blast.ncbi.nlm.nih. gov/Blast.cgi), ErGPCR belongs to methuselah-like proteins in the class B secretin GPCR family, but DmDopEcR shows homology with vertebrate ARs [24]. Identification and phylogenetic analysis using amino acid sequences show that ErGPCR differs from GPR30, beta-2 AR, or Drosophila DmDopEcR, which may explain the differences in ligand binding activity. Another possibility is the analytical method, which needs further study in next work. GPR30 has shown negligible binding to estrogen $(17 \beta$ estradiol) in several studies [49], which may be due to the different analytical methods [17]. A major challenge in the study of steroid hormone nongenomic pathways is the binding assay of GPCR with the steroid hormone [50]. Although ErGPCR did not bind ecdysteroid in our study, this result is of particular importance in many cellular responses to 20E, including 20E-induced mRNA levels, protein subcellular translocation and phosphorylation, and cellular $\mathrm{Ca}^{2+}$ increase. Whether other GPCRs can bind with $20 \mathrm{E}$ needs further exploration.

A total of 800 GPCRs have been discovered in mammals [51], 1000 in Caenorhabditis elegans [52], and 200 in D. melanogaster [53]. GPCRs involved in steroid membrane 
signaling may differ among various organisms. GPCRs form homodimers, heterodimers, oligomers, or complexes in the signalsomes of the membrane [54]. The mechanism underlying GPCRs in the 20E membrane pathway requires further study.

\section{Conclusions}

ErGPCR participates in 20E-regulated gene expression, rapid Calponin nuclear translocation and phosphorylation, rapid intracellular $\mathrm{Ca}^{2+}$ release, and extracellular $\mathrm{Ca}^{2+}$ influx via T-type calcium channels and TRP channels. The $\mathrm{N}$-terminal extracellular region is critical for the function of ErGPCR in the 20E signaling pathway. ErGPCR is necessary for the larval-pupal transition in $H$. armigera development (Figure 11).

\section{Methods and materials}

Insect

Cotton boll worms, $H$. armigera, were reared in our laboratory on an artificial diet of wheat, soybean, vitamins, and inorganic salts under a $14 \mathrm{~h}$ light:10 h dark cycle at $27^{\circ} \mathrm{C}$.

\section{Quantitative real-time reverse-transcriptase PCR (qRT-PCR)}

Approximately $5 \mu \mathrm{g}$ of the total RNA from each sample was reverse transcribed into first-strand cDNA for qRTPCR analysis (First Strand cDNA Synthesis Kit, Sangon, China). qRT-PCR was performed using SsoFast ${ }^{\text {tw }}$ EvaGreen Supermix (BIO-RAD, Shanghai, China). Thermocycling $\left(94^{\circ} \mathrm{C}\right.$ for $20 \mathrm{~s}, 58^{\circ} \mathrm{C}$ for $20 \mathrm{~s}$, and $72^{\circ} \mathrm{C}$ for $20 \mathrm{~s}$ ) was performed for 40 cycles using the CFX $96^{\text {max }}$ real-time system (BIO-RAD). The experiment was repeated three times using three independent RNA samples for statistical analysis. $\beta$-actin was used as the cDNA quality and quantity controls. The primers used for qRT-PCR are listed in Additional file 1: Table S2.

\section{Suramin inhibition}

$H$. armigera epidermal cells (HaEpi) cells were cultured until $80 \%$ confluence at $27^{\circ} \mathrm{C}$ in $25 \mathrm{~cm}^{2}$ culture flasks using Grace's medium (Invitrogen, Carlsbad, CA, USA) supplemented with $10 \%$ fetal bovine serum (FBS, Mdgenics, St. Louis, MO, USA). The cells were incubated with $50 \mu \mathrm{M}$ suramin (sodium salt; Sigma Chemical, St. Louis, MO, USA) for $1 \mathrm{~h}$ and then exposed to $1 \mu \mathrm{M}$ 20E for another $6 \mathrm{~h}$. Gene expression was determined via qRT-PCR.

\section{Screening of the target GPCR by qRT-PCR}

dsRNA was produced using a MEGAscript ${ }^{\text {ta }}$ RNAi kit (Ambion, Austin, TX, USA). Some GPCR ESTs obtained through random sequencing of the HaEpi cells, a cell line previously established in our laboratory, were individually knocked down using RNA interference. Lipofectamine 2000 (Invitrogen, Carlsbad, CA, USA) was used for dsRNA transfection. Briefly, $5 \mu \mathrm{g}$ of dsRNA and $8 \mu \mathrm{L}$ of Lipofectamine 2000 were added to $125 \mu \mathrm{L}$ of FBS-free Grace's medium incubated at room temperature for $30 \mathrm{~min}$. The reagents were mixed and incubated for another $20 \mathrm{~min}$,

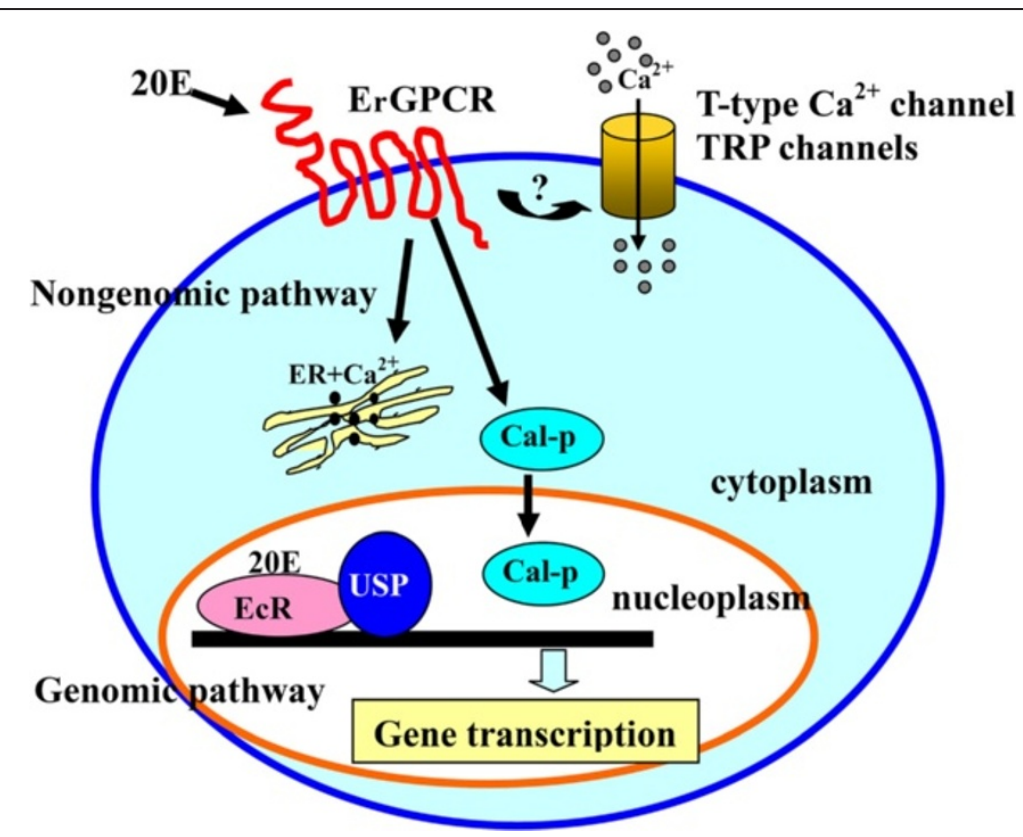

Figure 11 Diagram showing the ErGPCR-mediated nongenomic pathway response to 20E. 20E through ErGPCR nongenomic pathway regulates the cytosolic calcium fast increase, including the release of the intracellular $\mathrm{Ca}^{2+}$, and the influx of the extracellular $\mathrm{Ca}^{2+}$ via T-type calcium channels and TRP channels. 20E also through ErGPCR regulates the rapid phosphorylation and nuclear translocation of Calponin, and through ErGPCR regulates gene transcription in the genomic pathway for metamorphosis. 
and then directly added into HaEpi cells in a six-well plate containing $0.8 \mathrm{~mL}$ of Grace's medium per well. After incubation at $27^{\circ} \mathrm{C}$ for $24 \mathrm{~h}$, the cells were rinsed and then refed with fresh medium containing $10 \%$ FBS. The cells were cultured with $1 \mu \mathrm{M} 20 \mathrm{E}$ for $6 \mathrm{~h}$. Control cells were treated with the same amount of $d s G F P$. Total RNA was then extracted from the cells for qRT-PCR based on three independent replicates.

\section{Cloning of full-length cDNA of ErGPCR}

We obtained an EST with the 3' end of ErGPCR by random sequencing of the cDNA library of the insect during metamorphosis. The $5^{\prime}$ end of the gene was amplified via PCR using the gene-specific reverse primer ErGPCRF1 and the $5^{\prime}$ primer through the Genome Walker method as described by Clontech Laboratories Inc. (cat. no. 638904; Clontech, CA, USA).

Recombinant expression of ErGPCR in Escherichia coli and antiserum preparations

The ErGPCR fragment was amplified using the primers ErGPCRExpF and ErGPCRExpR. The PCR product was cloned into pET30a plasmid, expressed in Escherichia coli rosette cells, and then cultured in a Luria-Bertani medium ( $1 \%$ tryptone, $0.5 \%$ yeast extract, $1 \% \mathrm{NaCl}$, and $25 \mu \mathrm{g} / \mathrm{mL}$ kanamycin). The target protein was purified using His-bind resin to produce polyclonal rabbit antiserum. The specificity of the antibody was determined via western blot analysis using horseradish peroxidaselabeled goat anti-rabbit polyclonal secondary antibodies (Zhongshan, Beijing).

\section{Immunocytochemistry}

The cells grown on cover slips were fixed with 4\% paraformaldehyde in phosphate-buffered saline (PBS; $140 \mathrm{mM}$ $\mathrm{NaCl}, 2.7 \mathrm{mM} \mathrm{KCl}, 10 \mathrm{mM} \mathrm{Na} \mathrm{HPO}_{4}, 1.8 \mathrm{mM} \mathrm{KH} \mathrm{PO}_{4}$, $\mathrm{pH}$ 7.4) for $10 \mathrm{~min}$. The fixed cells were incubated with $0.2 \%$ Triton-X 100 in PBS for 8 min, blocked with 2\% bovine serum albumin (BSA) in PBS for $30 \mathrm{~min}$, and then incubated with primary antibody against the target gene (1:100 dilution in $2 \% \mathrm{BSA} / \mathrm{PBS}$ ) overnight at $4^{\circ} \mathrm{C}$. The cells were washed and then incubated with the ALEXA 488labeled goat anti-rabbit secondary antibodies (diluted $1: 1000$ in $2 \% \mathrm{BSA} / \mathrm{PBS}$ ) for $1 \mathrm{~h}$ at $37^{\circ} \mathrm{C}$. Nuclei were stained with DAPI $(1 \mu \mathrm{g} / \mathrm{mL}$ in PBS) for $10 \mathrm{~min}$. Fluorescence was detected using a Laser Scan Confocal Microscope Carl Zeiss LSM 700 (Thornwood, NY, USA).

ErGPCR overexpression and truncated mutation of ErGPCR PCR was used to prepare truncated mutations of ErGPCR. ErGPCR fragments were amplified via PCR with various primers (Additional file 1: Table S2) using proofreading DNA polymerase. The mutated ErGPCR was amplified via PCR using the ErGPCR fragments as templates. The open reading frame of ErGPCR and different mutated ErGPCRs were inserted into the pIEx-4 plasmid (Merck, Darmstadt, Germany), fused with GFP. The plasmid was transfected into HaEpi cells with Cellfectin following the protocol of the supplier (Invitrogen, Carlsbad, CA, USA). Afterward, $20 \mathrm{E}$ was added to the cells at a final concentration of $1 \mu \mathrm{M}$. An equal volume of DMSO was used as the solvent control for $20 \mathrm{E}$. DiI (1,1' -dioctadecyl-3,3,3',3' -tetramethylindocarbocyanine perchlorate; Beyotime, Shanghai, China) was used for plasma membrane staining.

\section{Examination of Calponin translocation and phosphorylation}

Subcellular Calponin translocation and phosphorylation were detected by immunocytochemistry and immunoblotting using rabbit polyclonal antibodies against Helicoverpa Calponin. After ErGPCR knockdown, the cells were treated with $1 \mu \mathrm{M} 20 \mathrm{E}$ for $0.5 \mathrm{~h}$ to $3 \mathrm{~h}$. Control cells were treated via the same method using GFP dsRNA. Fluorescence was detected using an Olympus BX51 fluorescence microscope. The phosphorylation analysis was performed by western blot.

\section{Calcium ion detection}

HaEpi cells were seeded and cultured for $72 \mathrm{~h}$ in a six-well tissue culture plate with $10 \%$ FBS Grace's medium at $27^{\circ} \mathrm{C}$. The cells were incubated with dsRNA for $24 \mathrm{~h}$ as previously described. The cells were incubated in a $3 \mu \mathrm{M}$ AM ester Calcium Crimson $^{\text {TM }}$ dye (Invitrogen, Carlsbad, CA, USA) in Grace's medium for $30 \mathrm{~min}$ at $27^{\circ} \mathrm{C}$. The cells were then washed with DPBS $\left(2.7 \mathrm{mM} \mathrm{KCl}, 1.5 \mathrm{mM} \mathrm{KH_{2 }} \mathrm{PO}_{4}\right.$, and $8 \mathrm{mM} \mathrm{Na}_{2} \mathrm{HPO}_{4}$ ) and exposed to $1 \mu \mathrm{M} 20 \mathrm{E}$ in DPBS for $2 \mathrm{~min}$ for detection of intracellular calcium release. Afterward, $1 \mathrm{mM}$ calcium chloride was added to induce extracellular calcium influx. Fluorescence was detected at $555 \mathrm{~nm}$ every $6 \mathrm{~s}$ for $360 \mathrm{~s}$ using a Laser Scan Confocal Microscope Carl Zeiss LSM 700 (Thornwood, NY, USA). Data were analyzed using the Image Pro-Plus software. For the inhibition experiments, the cells were pretreated with different inhibitors for $1 \mathrm{~h}$ prior to 20E treatment. The GPCR inhibitor suramin, T-type voltage-gated calcium channel inhibitor flunarizine dihydrochloride, L-type calcium channel inhibitor verapamil hydrochloride, and TRP channel inhibitors 2-APB and Pyr3 were purchased from Sigma Chemical (St. Louis, MO, USA).

\section{Chromatin immunoprecipitation (ChIP)}

The HaEpi cells were seeded in a six-well plate. Cells were transfected with pIEx-4-EcRB1-RFP at a density of $2 \times 10^{6}$. After $24 \mathrm{~h}$, the cells were transfected with dsErGPCR, and the controls were incubated with dsGFP. After $24 \mathrm{~h}$, the cells were subjected to either DMSO or $1 \mu \mathrm{M}$ 20E. After $6 \mathrm{~h}$, the cells were cross-linked with $0.5 \%$ formaldehyde at $37^{\circ} \mathrm{C}$ for $10 \mathrm{~min}$, followed by quenching at $0.125 \mathrm{M}$ glycine at room temperature for 
$10 \mathrm{~min}$. The cells were then washed with ice-cold $1 \times$ PBS and harvested at $6,000 \mathrm{rpm}$ for $5 \mathrm{~min}$. Cells were resuspended with SDS lysis buffer (1\% SDS, 10 mM EDTA, $50 \mathrm{mM}$ Tris- $\mathrm{HCl}, \mathrm{pH} 8.1$ ) and sonicated to yield average DNA fragments of $200 \mathrm{bp}$ to $1000 \mathrm{bp}$. After centrifugation to remove cell debris, the lysates were pre-cleared with protein $\mathrm{A}$ resin at $4^{\circ} \mathrm{C}$ for $1 \mathrm{~h}$, followed by incubation with no antibody (negative control) or anti-RFP antibody overnight. Immunoprecipitated protein-DNA complexes were incubated with protein $\mathrm{A}$ for an additional $2 \mathrm{~h}$ at $4^{\circ} \mathrm{C}$. The complexes were washed with low-salt buffer [0.1\% SDS, 1.0\% Triton X-100, 2 mM EDTA, $200 \mathrm{mM}$ Tris- $\mathrm{HCl}$ (pH 8.0), $150 \mathrm{mM} \mathrm{NaCl}]$ once, high-salt wash buffer $[0.1 \%$ SDS, 1.0\% Triton X-100, 2 mM EDTA, 20 mM Tris- $\mathrm{HCl}$ ( $\mathrm{pH} 8.0), 500 \mathrm{mM} \mathrm{NaCl}]$ once, $\mathrm{LiCl}$ wash buffer $[10 \mathrm{mM}$ Tris-HCl (pH 8.1), $0.25 \mathrm{M} \mathrm{LiCl,} 1$ mM EDTA, 1\% NP-40, $1 \%$ deoxycholate] once, and TE buffer $[10 \mathrm{mM}$ Tris- $\mathrm{HCl}$ ( $\mathrm{pH}$ 8.1), $1 \mathrm{mM}$ EDTA] two times. The bound proteins were eluted with elution buffer (1\% SDS, $0.1 \mathrm{M} \mathrm{NaHCO}_{3}$ ). DNA-protein crosslinks were reversed at $65^{\circ} \mathrm{C}$ overnight, followed by RNase and proteinase $\mathrm{K}$ treatment. DNA was purified with phenol/chloroform and ethanol precipitation, and analyzed by qRT-PCR using HHR3F/R primers (Additional file 1: Table S2). The negative control cells were transfected with the same volume of pIEx-4-RFP, and the cells received the same treatment as above.

\section{RNAi in larvae}

T7 promoter-containing PCR primers (GPCRRNA-iF, GPCRRNA-iR, GFPRNAiF and GFPRNAiR in Additional file 1: Table S2) were used to amplify the gene fragments. The PCR product purified with phenol-chloroform was used as a template to synthesize dsRNA using the MEGAscript RNAi Kit, as previously described. The dsRNA was diluted in nuclease-free water to $0.4 \mu \mathrm{g} / \mu \mathrm{L}$. Afterward, $5 \mu \mathrm{L}$ was injected into the fifth instar larvae at $6 \mathrm{~h}$ and at $30 \mathrm{~h}$, as well as into the sixth instar at $6 \mathrm{~h}$ and $30 \mathrm{~h}$. The controls were injected with $d s G F P$. Three independent experiments were performed using 30 larvae each.

\section{$\left[{ }^{3} \mathrm{H}\right]$ Pon A binding assays}

Cell membranes that express ErGPCR, EcRB1 and GFP were prepared from HaEpi cells with the plasmid ErGPCR-GFP-pIEx-4, EcRB1-GFP-pIEx-4, and GFP-pIEx-4. The details are as follows: cells were collected by centrifugation $\left(1700 \times \mathrm{g}, 10 \mathrm{~min}, 4^{\circ} \mathrm{C}\right)$ and then resuspended in $15 \mathrm{~mL}$ of HEPES buffer [20 mM HEPES, $6 \mathrm{mM} \mathrm{MgCl}_{2}$, $1 \mathrm{mM}$ ethylene diamine tetraacetic acid (EDTA), $1 \mathrm{mM}$ ethylene glycol bis (2-aminoethyl) tetraacetic acid (EGTA), $\mathrm{pH}$ 7.4]. After sonication, the homogenate was centrifuged at $1700 \times \mathrm{g}$ for $10 \mathrm{~min}$. The resulting supernatant was centrifuged at $48000 \times \mathrm{g}$ for $1 \mathrm{~h}$ at $4^{\circ} \mathrm{C}$. The pellet was resuspended in HEPES buffer, and the protein concentration was determined via the Bradford method. For the binding assay, a range of membrane fractions were incubated with $1 \mathrm{nM}\left[{ }^{3} \mathrm{H}\right]$ Pon A (Perkin Elmer, MA, USA) at $27^{\circ} \mathrm{C}$ for $1 \mathrm{~h}$ in $200 \mu \mathrm{L}$ of binding buffer (20 mM HEPES, $100 \mathrm{mM}$ $\mathrm{NaCl}, 6 \mathrm{mM} \mathrm{MgCl}_{2}, 1 \mathrm{mM}$ EDTA, $1 \mathrm{mM}$ EGTA). For the saturation experiments, reaction mixtures containing $50 \mu \mathrm{g}$ of the membrane fraction were incubated at $27^{\circ} \mathrm{C}$ for $1 \mathrm{~h}$ in the presence of the appropriate $\left[{ }^{3} \mathrm{H}\right]$ Pon A concentration in the binding buffer. Nonspecific binding was determined in the presence of $1 \mu \mathrm{M} 20 \mathrm{E}$. After incubation, particulate proteins were collected on glass fiber filters. The filters were then added to $5 \mathrm{~mL}$ of scintillation fluid. Radioactivity was determined using a SN-6930 liquid scintillation counter (Shanghai Hesuo Rihuan Photoelectric Instrument Co., Ltd., China). The whole cell binding experiments used the same method but without sonication and membrane preparation.

\section{Additional file}

Additional file 1: "The data sets supporting the results of this article are included within the article". Figure S1. Alignment of the GPCR ESTs obtained by random sequencing the Helicoverpa epidermal cell line. Figure S2. Screen of the target GPCR involved in 20E-induced gene expression by qRT-PCR. Figure S3. Nucleotide and deduced amino acid sequence of ErGPCR. Figure S4. Multiple alignments of ErGPCR with other G-protein-coupled receptors from different insects or vertebrates. Figure S5. Phylogenetic analysis of ErGPCR. Figure S6. 20E upregulates ErGPCR through ECRB1. Figure S7. The recombinant expression of ErGPCR fragments in E. coli. Table S1. Identification of the GPCRs. Table S2. Primers used in dsRNA synthesis and qRT-PCR.

\section{Abbreviations}

20E: 20-hydroxyecdysone; JH: Juvenile hormone; GPCR: G protein-coupled receptor; EcRB1: Ecdysone nuclear receptor B1; USP1: Ultraspiracle protein 1; HR3: Hormone receptor 3; BrZ2: Broad isoform Z2; DMSO: Dimethylsulfoxide; dsRNA: Double-stranded RNA; RNAi: RNA interference; GFP: Green fluorescent protein; RFP: Red fluorescent protein; HaEpi: An epidermal cell line from Helicoverpa armigera; FBS: Fetal bovine serum; DAPI: 4'-6-diamidino-2phenylindole dihydrochloride; BSA: Bovine serum albumin; TRP: Transient receptor potential; SOC: Store-operated channel; ROC: Receptor-operated channel; Dil: 1,1'-dioctadecyl-3,3,3',3'-tetramethylindocarbocyanine perchlorate; 2-APB: 2-aminoethoxydiphenyl borate; Cpm: Counts per minute of $\left[{ }^{3} \mathrm{H}\right]$ Pon A; qRT-PCR: quantitative reverse transcription polymerase chain reaction; ChIP: Chromatin immunoprecipitation; EcRE: Ecdysone response element.

\section{Competing interests}

The authors declare no conflict of interests.

\section{Authors' contributions}

Mei-Juan Cai performed the overexpression of ErGPCR and $\mathrm{Ca}^{2+}$ detection. Du-Juan Dong constructed the plEx-4-ErGPCR-GFP plasmid. Yu Wang cloned the gene. Wen Liu overexpressed ErGPCR in cell line. Peng-Cheng Liu examined the phosphorylation and translocation of Calponin. Jin-Xing Wang directed the research. Xiao-Fan Zhao designed the studies and wrote the manuscript. All authors read and approved the final manuscript.

\section{Acknowledgments}

This work was supported by the grants from the National Natural Science Foundation of China (No. 31230067) and the National Basic Research Program of China (973 Program, No. 2012CB114101) and Ph. D. Programs Foundation of Ministry of Education of China (No. 20120131110025). The L4440 and plEx-4 plasmids and HT115 (DE3) are kindly provided by Dr. Marek Jindra and Masako Asahina of the Biology Center, Czech Academy 
of Sciences and Department of Molecular Biology, University of South Bohemia, Czech Republic. We thank professor Lynn Moorhead Riddiford in Janelia Farm Research Campus, Howard Hughes Medical Institute in United States giving suggestions on preparing this manuscript.

GenBank number: JQ809653.

Received: 1 November 2013 Accepted: 3 February 2014

Published: 10 February 2014

\section{References}

1. Ratman D, Vanden Berghe W, Dejager L, Libert C, Tavernier J, Beck IM, De Bosscher K: How glucocorticoid receptors modulate the activity of other transcription factors: a scope beyond tethering. Mol Cell Endocrinol 2013, 380:41-54.

2. Parker MG, Arbuckle N, Dauvois S, Danielian P. White R: Structure and function of the estrogen receptor. Ann N Y Acad Sci 1993, 684:119-126.

3. Oro AE, McKeown M, Evans RM: Relationship between the product of the Drosophila ultraspiracle locus and the vertebrate retinoid $\mathrm{X}$ receptor. Nature 1990, 347:298-301.

4. Arbeitman MN, Hogness DS: Molecular chaperones activate the Drosophila ecdysone receptor, an RXR heterodimer. Cell 2000, 101:67-77.

5. Pratt WB, Galigniana MD, Morishima Y, Murphy PJ: Role of molecular chaperones in steroid receptor action. Essays Biochem 2004, 40:41-58.

6. Liu W, Zhang FX, Cai MJ, Zhao WL, Li XR, Wang JX, Zhao XF: The hormone-dependent function of $\mathrm{Hsp} 90$ in the crosstalk between 20-hydroxyecdysone and juvenile hormone signaling pathways in insects is determined by differential phosphorylation and protein interactions. Biochim Biophys Acta 2013, 1830:5184-5192.

7. Zheng WW, Yang DT, Wang JX, Song QS, Gilbert LI, Zhao XF: Hsc70 binds to ultraspiracle resulting in the upregulation of 20-hydroxyecdsoneresponsive genes in Helicoverpa armigera. Mol Cell Endocrinol 2010, 315:282-291

8. Bishop GJ, Koncz C: Brassinosteroids and plant steroid hormone signaling. Plant Cell 2002, 14(Suppl):S97-110

9. Mussig C, Altmann T: Brassinosteroid signaling in plants. Trends Endocrinol Metab 2001, 12:398-402.

10. Losel R, Wehling M: Nongenomic actions of steroid hormones. Nat Rev Mol Cell Biol 2003, 4:46-56.

11. Aronica SM, Kraus WL, Katzenellenbogen BS: Estrogen action via the CAMP signaling pathway: stimulation of adenylate cyclase and CAMP-regulated gene transcription. Proc Natl Acad Sci U S A 1994, 91:8517-8521.

12. Prossnitz ER, Maggiolini M: Mechanisms of estrogen signaling and gene expression via GPR30. Mol Cell Endocrinol 2009, 308:32-38.

13. Maggiolini M, Picard D: The unfolding stories of GPR30, a new membrane-bound estrogen receptor. J Endocrinol 2010, 204:105-114.

14. Revankar CM, Cimino DF, Sklar LA, Arterburn JB, Prossnitz ER: A transmembrane intracellular estrogen receptor mediates rapid cell signaling. Science 2005, 307:1625-1630.

15. Sanden C, Broselid S, Cornmark L, Andersson K, Daszkiewicz-Nilsson J, Martensson UE, Olde B, Leeb-Lundberg LM: G protein-coupled estrogen receptor 1/G protein-coupled receptor 30 localizes in the plasma membrane and traffics intracellularly on cytokeratin intermediate filaments. Mol Pharmacol 2011 79:400-410.

16. Cheng SB, Quinn JA, Graeber CT, Filardo EJ: Down-modulation of the G-protein-coupled estrogen receptor, GPER, from the cell surface occurs via a trans-Golgi-proteasome pathway. J Biol Chem 2011, 286:22441-22455.

17. Filardo EJ, Thomas P: Minireview: $G$ protein-coupled estrogen receptor-1, GPER-1: its mechanism of action and role in female reproductive cancer, renal and vascular physiology. Endocrinology 2012, 153:2953-2962.

18. Srivastava DP, Evans PD: GPER 1: trials and tribulations of a membrane oestrogen receptor. J Neuroendocrinol 2013, 25:1219-1230.

19. Hock T, Cottrill T, Keegan J, Garza D: The E23 early gene of Drosophila encodes an ecdysone-inducible ATP-binding cassette transporter capable of repressing ecdysone-mediated gene activation. Proc Natl Acad Sci U S A 2000, 97:9519-9524

20. Champlin DT, Truman JW: Ecdysteroid coordinates optic lobe neurogenesis via a nitric oxide signaling pathway. Development 2000, 127:3543-3551.

21. Thummel CS, Chory J: Steroid signaling in plants and insects-common themes, different pathways. Genes Dev 2002, 16:3113-3129.
22. Elmogy $M$, Iwami $M$, Sakurai $S$ : Presence of membrane ecdysone receptor in the anterior silk gland of the silkworm Bombyx mori. Eur J Biochem 2004, 271:3171-3179.

23. Manaboon M, Iga M, Iwami M, Sakurai S: Intracellular mobilization of Ca2+ by the insect steroid hormone 20-hydroxyecdysone during programmed cell death in silkworm anterior silk glands. J Insect Physiol 2009, 55:122-128.

24. Srivastava DP, Yu EJ, Kennedy K, Chatwin H, Reale V, Hamon M, Smith T, Evans PD: Rapid, nongenomic responses to ecdysteroids and catecholamines mediated by a novel Drosophila G-protein-coupled receptor. J Neurosci 2005, 25:6145-6155.

25. Gorelick-Feldman J, Cohick W, Raskin I: Ecdysteroids elicit a rapid Ca2+ flux leading to Akt activation and increased protein synthesis in skeletal muscle cells. Steroids 2010, 75:632-637.

26. Liu PC, Wang JX, Song QS XFZ: The Participation of Calponin in the cross talk between 20-hydroxyecdysone and juvenile hormone signaling pathways by phosphorylation variation. PLOS One 2011, 6:1-12.

27. Riddiford LM, Hiruma K, Zhou XF, Nelson CA: Insights into the molecular basis of the hormonal control of molting and metamorphosis from Manduca sexta and Drosophila melanogaster. Insect Biochem Mol Biol 2003, 33:1327-1338.

28. Chung WC, Kermode JC: Suramin disrupts receptor-G protein coupling by blocking association of $\mathrm{G}$ protein alpha and betagamma subunits. J Pharmacol Exp Ther 2005, 313:191-198.

29. Lopez-Lopez R, Langeveld CH, Pizao PE, van Rijswijk RE, Wagstaff J, Pinedo HM, Peters GJ: Effect of suramin on adenylate cyclase and protein kinase C. Anticancer Drug Des 1994, 9:279-290.

30. Shao HL, Zheng WW, Liu PC, Wang Q, Wang JX, Zhao XF: Establishment of a new cell line from lepidopteran epidermis and hormonal regulation on the genes. PLoS One 2008, 3:e3127.

31. Raz L, Khan MM, Mahesh VB, Vadlamudi RK, Brann DW: Rapid estrogen signaling in the brain. Neurosignals 2008, 16:140-153.

32. Vasudevan N, Pfaff DW: Membrane-initiated actions of estrogens in neuroendocrinology: emerging principles. Endocr Rev 2007, 28:1-19.

33. So HS, Park C, Kim HJ, Lee JH, Park SY, Lee ZW, Kim HM, Kalinec F, Lim DJ, Park R: Protective effect of T-type calcium channel blocker flunarizine on cisplatin-induced death of auditory cells. Hear Res 2005, 204:127-139.

34. Kovacs G, Montalbetti N, Simonin A, Danko T, Balazs B, Zsembery A, Hediger MA: Inhibition of the human epithelial calcium channel TRPV6 by 2-aminoethoxydiphenyl borate (2-APB). Cell Calcium 2012, 52:468-480.

35. Kiyonaka S, Kato K, Nishida M, Mio K, Numaga T, Sawaguchi Y, Yoshida T, Wakamori M, Mori E, Numata T, Ishii M, Takemoto H, Ojida A, Watanabe K, Uemura A, Kurose H, Morii T, Kobayashi T, Sato Y, Sato C, Hamachi I, Mori Y: Selective and direct inhibition of TRPC3 channels underlies biological activities of a pyrazole compound. Proc Natl Acad Sci U S A 2009, 106:5400-5405.

36. Lan Q, Hiruma K, Hu X, Jindra M, Riddiford LM: Activation of a delayed-early gene encoding MHR3 by the ecdysone receptor heterodimer EcR-B1-USP-1 but not by EcR-B1-USP-2. Mol Cell Biol 1999, 19:4897-4906.

37. Bender M, Imam FB, Talbot WS, Ganetzky B, Hogness DS: Drosophila ecdysone receptor mutations reveal functional differences among receptor isoforms. Cell 1997, 91:777-788.

38. Cai MJ, Liu W, He HJ, Wang JX, Zhao XF: Mod(mdg4) participates in hormonally regulated midgut programmed cell death during metamorphosis. Apoptosis 2012, 17:1327-1339.

39. Thomas P: Rapid steroid hormone actions initiated at the cell surface and the receptors that mediate them with an emphasis on recent progress in fish models. Gen Comp Endocrinol 2012, 175:367-383.

40. Christel C, Lee A: Ca2 +-dependent modulation of voltage-gated Ca2+ channels. Biochim Biophys Acta 2012, 1820:1243-1252.

41. Altier C: GPCR and Voltage-Gated Calcium Channels (VGCC) Signaling Complexes. Subcell Biochem 2012, 63:241-262.

42. Cioffi DL, Barry C, Stevens T: Store-operated calcium entry channels in pulmonary endothelium: the emerging story of TRPCS and Orai1. Adv Exp Med Biol 2010, 661:137-154.

43. Harteneck C, Klose C, Krautwurst D: Synthetic modulators of TRP channel activity. Adv Exp Med Biol 2011, 704:87-106.

44. Clapham DE: TRP channels as cellular sensors. Nature 2003, 426:517-524.

45. Yekkirala AS: Two to tango: GPCR oligomers and GPCR-TRP channel interactions in nociception. Life Sci 2013, 92:438-445.

46. Wagner TF, Loch S, Lambert S, Straub I, Mannebach S, Mathar I, Dufer M, Lis A, Flockerzi V, Philipp SE, Oberwinkler J: Transient receptor potential M3 
channels are ionotropic steroid receptors in pancreatic beta cells. Nat Cell Biol 2008, 10:1421-1430.

47. Clapham DE: Calcium signaling. Cell 2007, 131:1047-1058.

48. Rasmussen SG, DeVree BT, Zou Y, Kruse AC, Chung KY, Kobilka TS, Thian FS, Chae PS, Pardon E, Calinski D, Mathiesen JM, Shah ST, Lyons JA, Caffrey M, Gellman SH, Steyaert J, Skiniotis G, Weis WI, Sunahara RK, Kobilka BK: Crystal structure of the beta2 adrenergic receptor-Gs protein complex. Nature 2011, 477:549-555.

49. Otto C, Fuchs I, Kauselmann G, Kern H, Zevnik B, Andreasen P, Schwarz G, Altmann H, Klewer M, Schoor M, Vonk R, Fritzemeier KH: GPR30 does not mediate estrogenic responses in reproductive organs in mice. Biol Reprod 2009, 80:34-41.

50. Norman AW, Mizwicki MT, Norman DP: Steroid-hormone rapid actions, membrane receptors and a conformational ensemble model. Nat Rev Drug Discov 2004, 3:27-41.

51. Millar RP, Newton CL: The year in G protein-coupled receptor research. Mol Endocrinol 2010, 24:261-274.

52. Bargmann Cl: Neurobiology of the Caenorhabditis elegans genome. Science 1998, 282:2028-2033.

53. Adams MD, Celniker SE, Holt RA, Evans CA, Gocayne JD, Scherer SE, Venter JC: The genome sequence of Drosophila melanogaster. Science 2000, 287:2185-2195

54. Moreno JL, Holloway T, Gonzalez-Maeso J: G protein-coupled receptor heterocomplexes in neuropsychiatric disorders. Prog Mol Biol Trans/ Sci 2013, 117:187-205.

\section{Submit your next manuscript to BioMed Central and take full advantage of:}

- Convenient online submission

- Thorough peer review

- No space constraints or color figure charges

- Immediate publication on acceptance

- Inclusion in PubMed, CAS, Scopus and Google Scholar

- Research which is freely available for redistribution 